\title{
Het tijdperk van uitsluiting
}

Dr. Marion Herben, veldwerker,

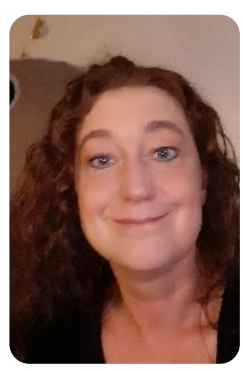
gedragswetenschapper en onderzoeker bij XtraPlus en Intermetzo in samenwerking met Philip Veerman, GZ-psycholoog bij XtraPlus en de Keijverlanden en Jolien van Aar, adviseur en onderzoeker bij VanMontfoort.

Wetenschappelijk onderzoek naar de toepassing van de methodieken Nieuwe Perspectieven (NP) en ReSet (Herben, 2019) laat zien dat deze hulp effectief is. Deze studie geeft evenzeer inzicht in de precaire leefomstandigheden en de sociale en maatschappelijke uitsluiting van ruim tweeduizend (dreigend) dak- en of thuisloze jongeren en de multiprobleemgezinnen waaruit deze jongeren vaak afkomstig zijn. Wat is er nodig om uitsluiting van deze personen die vaak kampen met psychische klachten, te voorkomen en hoe kunnen we uitgestotenen weer opnemen? De onderzoekers zochten naar een antwoord.

\section{Een tijdperk van uitsluiting maakt de noodzaak tot verbinden zichtbaar}

Wie het woord vrijheid opzoekt via Google treft daar 'In maatschappelijke zin behelst het de mogelijkheid van groepen en individuen om deel te nemen aan het maatschappelijke, economische en politieke verkeer [1]'. Vrijheid is niet voor iedere Nederlandse inwoner weggelegd. Al voor de uitbraak van COVID-19 stelde het Sociaal en Cultureel Planbureau dat drie tot vier procent van de volwassenen maatschappelijk niet goed meekan en daarbij ongelukkig is $[2,3]$. In een eventuele economische crisis als gevolg van het coronavirus, zal het aantal personen toenemen dat onder de armoedegrens leeft en vanwege geldgebrek wordt uitgesloten van deelname in de maatschappij. Net als hun zorgen. Ook het aantal dakloze jongeren en het aantal 'verwarde mensen' groeit nog steeds [4]. Dit pleit voor een aanpak met een verbinding tussen generalistische en specialistische hulp.

De resultaten van methodieken Nieuwe Perspectieven (NP) en ReSet (zie ander kader) zijn onafhankelijk van elkaar op zeven verschillende locaties onderzocht. In beide studies is gebruik gemaakt van een vergelijkbaar onderzoeksdesign; een mixed-methods benadering met kwalitatief en kwantitatief onderzoek waarbij alle type data steeds op elkaar zijn betrokken. Ruim 1600 jongeren, bijna 400 gezinnen en 150 professionals hebben deelgenomen aan het onderzoek door middel van interviews, focusgroepen, praktijkexperimenten, dossieronderzoek, vragenlijsten en resultaatformulieren. De volgende uitkomstmaten zijn meegenomen: De inhoudelijke begeleidingsactiviteiten en ondersteuningsbehoeften op meerdere domeinen (o.a. basiszaken, opvoeding, inkomen, gezondheid en dagbesteding), (al dan niet modelgetrouw) handelen van de begeleider, doelgroepkenmerken, de wensen en perspectieven van jongeren, ouders, managers, verwijzers en gemeenten en de GAS-scores op de doelen. 


\section{Permanente aandacht}

Het tegengaan van uitsluiting van groepen in de samenleving heeft in het Corona tijdperk gelukkig meer aandacht gekregen.

Bij een groter deel van de bevolking lijkt door te dringen dat een ieder het risico loopt om buiten de boot te vallen. De Raad voor Volksgezondheid en Samenleving [4] vraagt om permanente aandacht voor uitsluiting en stelt dat een plek om te wonen aan de basis zou moeten staan van elk passend hulpverleningstraject. De raad stelt voorts dat de regels en procedures die zijn bedoeld om het probleem van uitsluiting te voorkomen het tegenovergestelde bereiken: Ze duwen mensen in een kwetsbare positie verder naar de rand van de samenleving. Beide stellingen van de raad worden onderschreven in het proefschrift Effectief Verbinden van Marion Herben [5]. Daarbij wordt wel de nuance gemaakt dat het Housing First principe (dat start met het aanbieden van huisvesting) niet zomaar van volwassenen naar jongeren kan worden gekopieerd, zoals ook al eerder gesteld door Judith Wolf e.a. [6]. Bij veel dakloze jongeren is er sprake van een meervoudige ondersteuningsbehoefte (financieel, psychisch, relationeel). Het zelfstandig wonen wordt gezien als een grote opgave met veel

verantwoordelijkheid. Er is angst voor falen, een te grote verantwoordelijkheid, en voor sociaal isolement.

\section{Een hek om kwetsbare personen}

De overheid doet sinds de decentralisaties een groter beroep op burgers en verwacht van hen meer zelfredzaamheid. We leven in een veeleisende samenleving als het gaat om vaardigheden, zelfbeheersing of weerbaarheid [7]. Veranderingen gaan snel en het risico op uitval is groot. Er zijn mensen op wie het adagium van zelfredzaamheid niet van toepassing is en ook niet zal worden. De institutionalisering van de samenleving heeft met zijn wirwar aan regels en voorwaarden een wig gedreven tussen personen die te veel afwijken van gemiddelden en hun mogelijkheden tot sociale en maatschappelijke deelname. Een groot deel van de personen bij wie de problemen zich opstapelen, krijgt ondersteuning vanuit onder meer de Participatiewet, Jeugdwet en Wmo. Maar de vele regels en procedures duwen kwetsbare mensen niet alleen naar de rand van de samenleving, zoals de raad in haar rapport stelt. Met de voorwaarden die de samenleving aan haar deelnemers stelt wordt er als het ware een hek om deze personen geplaatst. Doordat er personen niet kunnen meedoen, boos zijn of zich juist meer terugtrekken wordt de cirkel in stand gehouden. Als reactie op het hek geven ze de hoop op en groeit hun passiviteit of agressiviteit.

Nieuwe Perspectieven (NP), in 2007 doorontwikkeld en beschreven door VanMontfoort, is een intensieve

begeleidingsvorm voor jongeren in de leeftijd van 12 tot 24 jaar met overlast- gevend gedrag. Deze jongeren zijn (dreigend) dak- en / of thuisloos en meer dan de helft heeft (eerdere) politie- en / of justitie-contacten. Bijna de helft van deze jongeren kampen met psychische klachten. NP stelt als doel dat jongeren maatschappelijk participeren.

ReSet, in 2011 ontwikkeld en beschreven door $\mathrm{JSO}$, is een vorm van Intensieve Pedagogische Thuishulp. Deze ambulante begeleidingsvorm op maat is bedoeld voor risico- en multiprobleemgezinnen met ten minste één thuiswonend minderjarig kind. Veel ouders kampen met psychische klachten. ReSet heeft als doel dat ouders de opvoeding van de kinderen weer zelfstandig ter hand kunnen nemen. 


\section{Uitgestotenen terugbrengen}

Wie eenmaal is buitengesloten kan niet zomaar door het hek stappen. Dakloze jongeren missen voorliggende documenten (ID-kaart) en voorzieningen (GBAinschrijving) wat in het traject tot ingewikkelde vicieuze cirkels kan leiden. Een verblijf in de daklozenopvang dat bestaat uit 's avonds erin en in de ochtend eruit' lost niets op. Bovenal kost het de maatschappij erg veel geld. Het geeft deze jongeren een gebrek aan rust en stabiliteit en maakt plannen vrijwel onmogelijk (waarin ze überhaupt nog moeten groeien). Het gebrek aan bestaanszekerheid maakt hen somber en gespannen. De Nederlandse vrede en vrijheid waar staatssecretaris Blokhuis op Bevrijdingsdag dit jaar over sprak gaat vooralsnog volledig aan hen voorbij. En komt maar niet dichterbij. Geen stabiel inkomen en huis betekent geen toegangsbewijs tot de maatschappij. Ook voor multiprobleemgezinnen die vaak in armoede leven, geldt dat voorzieningen op orde moeten zijn voordat een oplossing voor de schulden kan worden gevonden en met het verder waarborgen van de basiszorg voor één of meer kind(eren) aan de slag kan worden gegaan. Als een GBA inschrijving niet kloppend is kunnen gezinnen bijvoorbeeld toeslagen mislopen of mogelijkheden tot inkomstenaanvullingen waardoor het inkomen onder het bestaansminimum blijft. Het waarborgen van zorg kan gaan over het voorbereid zijn op de komst van een baby, medische zorg, veiligheid of voldoende en gezonde voeding voor kinderen. Sommige kinderen

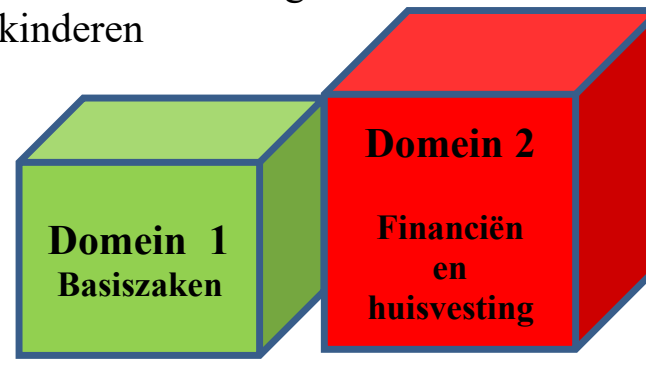

dragen door geldgebrek geen passende kleding. Er zijn kinderen die zomers in winterkleding rondlopen of meisjes die jongenskleding dragen en andersom.

Sommige kinderen hebben geen

buitenactiviteiten of omgang met leeftijdgenoten. Zij worden binnengehouden door depressieve ouders en verblijven sinds ver voor het uitbreken van het corona-virus in quarantaine. Omdat jongeren en gezinnen veel problemen hebben op meerdere domeinen die allen in verbinding met elkaar staan, is het zinloos om deze kwetsbaren op losse onderdelen te ondersteunen. In de hulpverlening blijkt een totaalaanpak noodzakelijk.

\section{Een generalistisch aanbod op vier domeinen}

Effectieve hulp, zoals die uit het promotieonderzoek naar voren komt, begint bij aandacht voor de basiszaken. Daarbij kan het gaan om een verzekering tegen ziektekosten, bed - bad - brood of een fondsaanvraag voor de niet vergoede tandartskosten of missende documenten en voorzieningen. Met het regelen van deze zaken wordt de uitgeslotenen als het ware tot aan 'de poort van het hek' gebracht. In geval van ReSet wordt bij ouders met psychische klachten daarna gestart met een warme overdracht naar een vorm van GGZ. Zodra de GGZ begeleiding een feit is kan de ReSet begeleiding 
daarnaast lopen.

Domein twee omvat het openen van de deur, terug naar de samenleving. Voor veel jongeren strekt een begeleide woonvorm tot de aanbevelingen. Onderzochte NPorganisaties beschikken over woonvormen die variëren van lichte naar zwaardere begeleiding. Bij ReSet kan het gaan om verbeterde huisvesting (woning te duur, te klein of in geval van overlast) of het voorkomen van huisuitzetting. Met het op orde brengen van de financiën (voldoende inkomen, een oplossing voor eventuele schulden) en huisvesting wordt sociale en maatschappelijke participatie weer mogelijk. Er kan weer bezoek worden ontvangen en er is geld voor de kapper. In de praktijk loopt de realisatie van de doelen basiszaken, een gezonde financiële situatie en stabiele huisvesting naast elkaar. Eenmaal weer sociaal en maatschappelijk toegetreden blijkt dat juist eerdere dak- en thuisloze jongeren de nodige persoonlijke uitdagingen (domein 3) moeten overwinnen. Psychische klachten of middelenmisbruik maken economische participatie in de vorm van scholing en werk (domein 4) voor deze groep vooralsnog onmogelijk. Voor het inschakelen van hulp door een psycholoog zijn opnieuw praktische zaken, zoals het beschikken over een huisarts (in verband met de verwijsbrief), een passende zorgverzekering (in verband met de kosten van de behandeling) en jezelf van A naar B kunnen vervoeren (vermindert de kans op no-shows) [8], voorwaardelijk aan een succesvolle toeleiding. Maar die zijn dan inmiddels op orde.

\section{De verbinding naar specialistisch hulp} Een begeleiding aan kwetsbare personen met een multipele ondersteuningsbehoefte vraagt om een nauwlettende op elkaar afgestemde generalistische en specialistische aanpak.

Sinds de eerste overheveling van de curatieve- GGZ in 2008 vanuit de AWBZ naar de Ziekenfondswet, dient er bij personen met psychische klachten op korte termijn een diagnose te worden gesteld waarop zorgverzekeraars hun vergoedingen kunnen baseren. Deze overheveling heeft een toeleiding naar GGZ-organisaties voor NP-jongeren met meervoudige problemen tussen de 17 en 24 jaar niet vergemakkelijkt. Met als uiteindelijk doel dat jongeren succesvoller kunnen worden toegeleid naar de juiste specialistische behandelaar heeft een onderzochte NP-organisatie in 2018 een GZ-psycholoog in dienst genomen. De psycholoog trekt gezamenlijk op met jongeren en speelt een rol in het gemotiveerd houden van deze jongeren voor externe ondersteuning door middel van contactonderhoud en overleg met netwerkpartners tijdens de wachtperiode. Daarnaast wordt er waar nodig diagnostisch onderzoek verricht en verwezenlijkt de GZ-psycholoog een bredere samenwerking met meer kleinschalige, specialistische netwerkpartners.

\section{Uitsluiting voorkomen is beter dan genezen}

Het realiseren van de volgorde in dit begeleidingsproces met aandacht voor de vier domeinen en een verbinding tussen een meer generalistische aanpak en de specialistische zorg, blijkt van essentieel belang voor het succes. Maar het meest effectief is zorgen dat de basis op orde blijft en voorkomen dat personen worden uitgesloten. Dat kan door tijdige zorg voor elkaar. Dan vermindert de kans op psychische en fysieke klachten, dak- en thuisloosheid, in de schulden belanden, uitval op school / werk, overlastgevend of 
crimineel gedrag en het belanden in een sociaal isolement. Zoals Jette Bussemaker onlangs sprak, verdient iedere euro zich bij preventie dubbel en dwars terug. Wellicht leert de coronacrisis ons dat voor elkaar zorgen een fundamentele waarde heeft voor het leven.

\section{Hoe verder?}

Naar aanleiding van de bevindingen uit het onderzoek werken Xtra en VanMontfoort aan de doorontwikkeling van de interventie Nieuwe Perspectieven. Nieuwe

Perspectieven Nieuwe stijl wordt opnieuw ingediend in de Databank Effectieve Jeugdinterventies van het Nederlands Jeugdinstituut.

Voor meer informatie over ReSet kunt $\mathrm{u}$ contact opnemen met JSO, Nita van Veluw n.van.veluw@jso.nl.

\section{Literatuurlijst}

1. Wikipedia. Vrijheid (sociologie). 2020 3-3-2020 [cited 2020 1-102020].

2. $\mathrm{SCP}$, De sociale staat van Nederland 2018. 2018.

3. SCP, De sociale staat van Nederland 2019. 2019: Den Haag.

4. RVS, Herstel begint met een huis, in Dakloosheid voorkomen en verminderen. 2020: Den Haag.

5. Herben, M.M.C., Effectief verbinden. Resultaatgerichte (door)ontwikkeling van interventies, B.T. BV., Editor. 2019: Rotterdam.

6. Wolf, J. and A. Peters Housing First voor jongeren, in https://housingfirstnederland.nl/wp content/uploads/2018/12/Informati eblad-Housing-First-voorjongeren-1.pdf, I.O.m.z.v.h. Radboudumc, Editor. 2018, Radboudumc: Nijmegen.

7. Herben, M.M.C. and A. Hoogveld, Belemmerende factoren voor de modelgetrouwheid, J.I. Team, Editor. 2017: Den Haag.

8. de Haan, A.M., Ethnic minority youth in youth mental health care: utilization and dropout. 2014. 